\title{
İmalat Sanayi Sektöründe Kârlılığın Belirleyicileri: TCMB Sektör Bilançolarıyla Panel Veri Analizi (1996-2015)
}

\author{
The Determinants of Profitability in Manufacturing Industry Sector: \\ Panel Data Analysis with CBRT Sectoral Balance Sheets (1996-2015)
}

\author{
N.Savaş DEMIRCi ${ }^{1}$
}

\begin{abstract}
ÖZET
Ticari işletmeler faaliyetlerini sürdürebilmek ve uzun dönemde büyüyebilmek için yeterli düzeyde kâr etmek zorundadır. Kârlıık özellikle Türkiye'nin de içinde bulunduğu gelişmekte olan ülkelerde ihracat, istihdam ve inovasyon kanallarıyla ekonomik büyümeye katkı sağlayan ve sanayi sektörünün en büyük alt sektörünü oluşturan imalat sanayi sektöründe daha da önemli hale gelmektedir. Çalışmada, imalat sanayi sektöründe kârlılığın işletme düzeyindeki başlıca belirleyicileri, ülkemizdeki en kapsamlı reel sektör veri seti olan Türkiye Cumhuriyet Merkez Bankası (TCMB) sektör bilançolarından yararlanılarak 19962015 döneminde iki yönlü panel veri analizi ile incelenmiştir. Ekonometrik analiz sonuçları; Türkiye imalat sanayi sektöründe aktif kârlılık oranının kaldıraç oranı ve maddi duran varlıkların toplam varlıklara oranından negatif, alacak devir hızı ve reel aktif büyüklüğünden pozitif olarak etkilendiğini ortaya koymaktadır. Analiz sonuçlarına göre kârlılığını artırmakisteyen işletmeler daha azyabancı kaynak kullanmalı, maddi duran varlık verimliliğini artırmalı ve alacaklarını satışlarını etkilemeden daha hızlı tahsil etmelidir. İmalat sanayi sektöründe genel kârlılık oranının artması ekonomik büyüme ve kalkınmayı da hızlandıracaktır.
\end{abstract}

Anahtar kelimeler: Kârlılık, İmalat Sanayi Sektörü, Panel Veri Analizi, TCMB Sektör Bilançoları

\begin{abstract}
Businesses have to make sufficient profits to sustain activities and grow in the long run. Profitability is important especially in manufacturing industry sector that contributes to economic growth through export, employment and innovation channels in developing countries including Turkey and is the largest subsector of industry sector. In this article main determinants at firm level of profitability have been searched with the Central Bank of the Republic of Turkey (CBRT) sectoral balance sheets which is the largest real sector data set in our country by using two-way panel data analysis in the period 1996-2015. Econometric analysis results show that in Turkish manufacturing industry sector return on assets is negatively affected by leverage ratio and tangible assets to total assets ratio and positively affected by accounts receivables turnover and real volume of assets. According to results of analysis businesses wanting to increase profitability should use less debt, enhance efficiency of tangible assets and collect receivables without decreasing sales. The rise of general profitability level in manufacturing industry is going to boost economic growth and development.
\end{abstract}

Key words: Profitability, Manufacturing Industry Sector, Panel Data Analysis, TCMB Sectoral Balance Sheets

\section{Gíriş}

Bütün ticari işletmeler faaliyetlerini sürdürebilmek ve uzun dönemde büyüyebilmek için yeterli düzeyde kâr ortaya koymak zorundadır. Kârlı faaliyetler sadece işletmelere değil makro ölçekte ekonomik büyümeye ve refah artışına da katkı sağlamaktadır. İsletmelerde kâr işletme değeriyle de yakından ilişkilidir. Mevcut yatırımlar sonucu ortaya çıkan kâr ve mevcut/yapılacak yatırımlardan gelecekte üretilmesi beklenen kârlar işletmenin değerini belirlemektedir. Kâr etmenin işletmeler için çok stratejik bir olgu olması bağlamında işletmelerin kaynaklarını kullanarak kâr ortaya koyma gücünü ve oranını ifade eden kârlılığın hangi dinamiklerle sağlandığı çeşitli modellerle açıklanmaya çalışıımıştır. Bu modellerden 
yapı-davranış-performans (structure-conduct-performance) modeline göre işletmenin davranışını ve kârlııı̆ını piyasa yapısı etkilemektedir. Modele göre rekabetin zayıf olduğu sektörlerde işletmeler daha kârlı faaliyet gösterirken, rekabetçi piyasalarda işletmeler daha düşük kârlılıklarla faaliyet göstermektedir. Geniş çevrelerce kabul gören bir diğer yaklaşım olan işletme-etkileri (firm-effects) modelinegöre de işletme faaliyetlerine ve yapısına bağlı olarak ortaya çıkan yüksek verimlilik, verimli işletmelere diğer işletmeler karşısında rekabet avantajı kazandırır ve rekabetçi üstünlük yüksek kârlılığa neden olur. Bu modele göre işletmelerin ayrışımı ve kârlııkları piyasa yapısını belirlemektedir (Slade, 2004: 290-293; Stierwald, 2009: 1-4). Grant (1991); uluslararası rekabetin hızlanması, teknolojik gelişmelerin yoğunlaşması ve işletmelerin sektörlerin sınırlarını aşacak şekilde farklılaşmasıyla kârlılığın daha çok işletmelerin rekabet gücü kaynaklarına bağlı olarak işletme düzeyinde belirlendiğini savunmaktadır. Aynı yazara göre kârlııı; işletme büyüklüğü, finansman, maddi duran varlıklar, ucuz işgücü ve hammadde, teknoloji, pazar payı, marka, patent, servis ve satış ağı gibi kaynaklardan yüksek verimlilikle faydalanmayı hedefleyen işletme stratejilerine dayanmaktadır. Iş̧letmelerin uyguladıkları ilgili stratejilerinin sonuçları da işletmelerin bilanço ve gelir tablolarına finansal kalemler aracılığıyla doğrudan ya da dolaylı olarak büyük oranda yansıdığından dolayı kârlııı̆ı belirleyen değişkenleri konu alan analizlerde çoğunlukla finansal oranlar tercih edilmektedir. Kârlılık analizi işletmelerin finansal performanslarının ölçülmesinde sıklıkla kullanıldığından, kârlılık dinamiklerini açıklamaya çalışan analizler işletmenin finansal performansı hakkında da bilgi sağlamaktadır. Finansal olmayan performansla birlikte işletme performansını ifade eden finansal performans, tek başına işletme performansını açıklama noktasında yeterli olmamakla beraber performansın başlıca bileşeni olma özelliğini günümüzde de korumaktadır. İşletmenin finansal olarak hangi noktada olduğunun belirlenmesi ve ileriye yönelik finansal yönetime dair kararların alınabilmesi için finansal performansın kârlılık ekseninde ölçülmesi ve analiz edilmesi işletmeler açısından zorunludur (Otley, 2002: 3-4).

İşletmelerin ve ülke ekonomilerinin sürdürülebilirliği açısından büyük önem taşıyan kârlılığın dünya genelinde sanayi sektörünün en büyük alt sektörü konumunda bulunan imalat sanayinde analiz edilerek reel sektörün kaynaklarını kârlılığa dönüştürme gücünün yorumlanması, ekonomiler açısından önem arz ermektedir. Üretim ve istihdamdaki yüksek payına ek olarak dahil olduğu tedarik zinciriyle diğer sektörler üzerinde çarpan etkisi yaratan, inovasyon liderliği yapan ve diğer sektörlere göre daha hızlı sermaye birikimi sağlayan imalat sanayi sektörü; ürün çeşitliliğiyle ülkelerin ihracatlarını da desteklemektedir. Gelişmiş imalat sanayi altyapısına sahip ülkeler, istikrarlı döviz kurlarına ve büyüme oranlarına sahip olmakla birlikte sektör birçok alt sektörden oluştuğu için de sektörel ve sistemik şoklara karşı ekonomiyi daha dayanıklı hale getirmektedir (Ritchie vd., 2012: 4). İmalat sanayi, ekonomiler içindeki payı azalmasına rağmen, halen gelişmiş ülkelerde verimlilik artışına, inovasyona ve ihracata ciddi katkılar sağlamanın yanında gelişmekte olan ülkelerde de ekonomik büyümenin ve refah artışının kilit sektörü konumundadır (McKinsey, 2012: 17). İmalat sanayi sektörü, günümüzde dünya genelinde olduğu gibi Türkiye'de de, ekonomi içindeki katma değer payı daralmakla birlikte, önemini halen korumaktadır. 2000'de katma değer içindeki payı \%22'den 2014'te \%18'e düşen ülkemiz imalat sanayi sektörü, 2014 itibariyle mal ihracatının \%77'sini, 2015 verilerine göre de ülkedeki toplam istihdamın \%19'unu karşılamaktadır (WTO, 2015: 91; tuik.gov. tr). Bu noktada ülkemiz ekonomisi için de son derece stratejik bir sektör konumunda bulunan imalat sanayinde kârlılık analizi önemli hale gelmektedir. Gönenç ve Yılmaz (2007) da kârııık endeksleri ile yaptıkları analizde, imalat sanayi sektöründe kârlı faaliyet gösteren işletmelerin daha fazla ürettiğini, daha fazla ihracat yaptığını ve daha fazla istihdam yarattığını vurgulamış ve sektörde kârlılık düzeyinin önemli olduğunu belirtmişlerdir.

Bu bağlamda on bine yakın işletmenin finansal bilgilerini içermesiyle en kapsamlı reel sektör veri seti kabul edilen Türkiye Cumhuriyet Merkez Bankası (TCMB) sektör bilançolarından yararlanmasıyla ve alt sektörlerin toplulaştırılmış verilerini dikkate almasıyla diğer benzer çalışmalardan ayrılan bu çalışma; ülkemiz ekonomisinin sürükleyici sektörü konumunda bulunan imalat sanayi sektöründe, kârlıı̆ın işletme düzeyindeki başlıca belirleyicilerini panel veri analiziyle ortaya koymayı amaçlamaktadır. $\mathrm{Bu}$ amaçla öncelikle literatür araştırılmakta ve daha sonra da 1996-2015 yıllarını kapsayan döneme ilişkin ekonometrik analiz sonuçlarına yer verilmektedir. Çalışma, benzer çalışmalarla kıyaslandığında oldukça geniş bir veri setine dayandığından, elde edilecek analiz sonuçları imalat sektörüyle ilgili daha genelleyici yorumlara olanak sağlayabilecektir. 


\section{LITERATÜR}

Türkiye'de imalat sanayi sektöründe kârlılığı etkileyen faktörleri araştıran çalışmalarda ağırlıkla borsaya kote işletmelerin verileri kullanılmıştır. Aydeniz (2009), makroekonomik göstergelerin işletmelerin kârlılıklarına etkisini araştırdığı çalışmasında 31 gıda ve içecek işletmesinin 1998-2007 dönemine ait verilerini doğrusal regresyon analizinde kullanmıştır. Aktif kârlılık oranı, özkaynak kârlııı oranı, satışların kârlılık oranı, faiz ve vergi öncesi kâr ve faiz, vergi ve amortisman öncesi kârın bağımlı değişkenler olarak kullanıldığı ve beş farklı modelin kurulduğu çalışmada; aktif kârlılık oranı ile tüketici fiyatları endeksi değişim oranı, faiz oranları, Gayri Safi Milli Hasıla büyüme oranı, kapasite kullanım oranı ve dış ticaret dengesi arasında pozitif ilişki, aktif kârlılık oranı ve üretici fiyatları endeksi değişim oranı arasında negatif ilişki elde edilmiştir. Özkaynak kârlılık oranının bağımlı değişken olarak kullanıldığı modelde ise ilgili oran ile sadece üretici fiyat endeksi arasında ve negatif yönlü bir ilişkinin olduğu ortaya konulmuştur. Saldanlı (2012); 2001-2011 yıllarını kapsayan ve Borsa İstanbul'a kote 54 imalat sanayi işletmesinde likidite ve kârlılık ilişkisini çoklu regresyon analiziyle incelediği çalışmasında aktif kârlılık oranı ile cari oran, asit test oranı ve nakit oranı arasında negatif ilişkiler tespit etmiştir. Aygün (2012); çalışma sermayesinin işletmenin finansal performansına etkisini araştırdığı çalışmasında, hisseleri Borsa İstanbul'da işlem gören 107 imalat sanayi işletmesinin 2000-2009 dönemine ait verilerini kullanmıştır. Çalışmada bağımlı değişken aktif kârlılık oranı ile nakit dönüşüm süresi ve kaldıraç oranı arasında negatif; aktif kârlııı̆ı ile aktif büyüklüğü, cari oran ve satışların büyüme oranı arasında anlamlı pozitif ilişkiler tespit edilmiştir. Meder Çakır ve Küçükkaplan (2012), işletme sermayesi unsularının kârııı̆a etkisini araştırdıkları ve Borsa İstanbul'a kote 122 imalat sanayi işletmesinin 20002009 dönemine ilişkin verilerinden yararlandıkları çalışmalarında aktif kârılık oranının bağımlı değişken olarak kullanıldığı panel regresyon modeli kurmuşlar ve kârlılığın asit test oranı, stok devir hızı ve aktif devir hızından pozitif; cari oran ve kaldıraç oranından ise negatif olarak etkilendiği sonucuna ulaşmışlardır. Özmen, Şahinöz ve Yalçın'ın (2012), TCMB sektör bilançoları veri setini kullanarak altı bine yakın imalat sanayi işletmesinin 1996-2008 dönemine ait verilerini panel veri analizi ile inceledikleri çalışmalarına göre kârlılık işletme büyüklüğünden, ihracat yoğunluğundan, reel Gayri Safi Yurtiçi Hasıla (GSYiH) büyüme oranından, finansal gelişmişlikten pozitif; kaldıraç oranından, kamu borcunun GSYiH'ya oranından, varlık yapısından ve reel döviz kurundan ise negatif olarak etkilenmektedir. Uluyol vd. (2014); 1991-2012 dönemini üç aylık verilerle inceledikleri ve Borsa İstanbul'a kote işletmeleri sektör ölçeğinde dikkate alarak kaldıraç oranının özkaynak kârlılığına etkisini ARDL sınır testi yaklaşımıyla dikkate aldıkları çalışmalarında kaldıraç oranının bilişim, gıda, madencilik ve tekstil sektörlerinde özkaynak kârlılığına negatif, inşaat sektöründe ise bağımlı değişkene pozitif etkide bulunduğu sonuçlarına ulaşmışlardır. Korkmaz ve Karaca (2014), İmalat Sanayi Endeksi'nde yer alan 78 işletmenin 2000-2011 yılları arasındaki verilerini kullanarak, seçili finansal oranların kârlılığa etkilerini analiz etmişler ve hisse başına kâr, özkaynak kârlılık oranı ve aktif kârlılık oranının bağımlı değişken olarak yer aldığı panel veri modelleri kurmuşlardır. Çalışmada kaldıraç oranının ve duran varlıkların aktiflere oranının tüm bağımlı değişkenleri negatif; maddi duran varlıkların uzun vadeli yabancı kaynaklara oranının da hisse başına kârı negatif diğer iki bağımlı değişkeni de pozitif olarak etkilediği tespit edilmiştir. Doğan ve Topal (2016); 2005-2012 dönemi yıllık verileriyle hisseleri Borsa İstanbul'da işlem gören 136 imalat sanayi işletmesinin kârlılık dinamiklerini panel veri analizi kullanarak inceledikleri çalışmalarında aktif ve özkaynak kârııık oranlarının bağımlı değişken olarak yer aldığı iki model kurmuşlardır. Analiz sonuçları; her iki bağımlı değişkenin kaldıraç oranından negatif aktif büyüklüğünden ise pozitif olarak etkilendiğini göstermektedir. Keskin ve Gökalp (2016), Borsa İstanbul'a kayıtlı 17 gıda ve içecek sektörü işletmesinde çalışma sermayesi yönetiminin aktif kârlılık oranı ile olan ilişkisini 2009-2013 dönemi yıllık verilerinden yararlanarak panel veri analiziyle incelemişlerdir. Çalışmada cari oranın, kaldıraç oranının ve alacak tahsil süresinin aktif kârlıığını negatif yönde etkilediği ortaya konulmuştur. Kocaman vd. (2016); hisseleri Borsa İstanbul'da işlem gören, İstanbul Sanayi Odası 100 arasında yer alan ve çoğunluğunu imalat sanayi işletmelerinin oluşturduğu 15 işletmenin 1997-2013 dönemine ilişkin yıllık verilerini dikkate alarak yaptıkları çalışmada, bağımlı değişken olarak aktif kârlıık oranını kullanmışlardır. Panel veri analizinin sonuçlarına göre kârılığı alacak devir hızı ve net kâr marjı pozitif, kaldıraç oranı ve duran varlıkların aktiflere oranı ise negatif etkilemektedir.

Türkiye dışında imalat sanayi sektöründe kârlııı̆ı analiz eden başlıca yazarlardan Ratnayake (2000); Yeni Zelanda'nın 109 imalat sanayi alt sektöründe 1986-1987 dönemi verileriyle kârlılık dinamiklerini 
regresyon analizi ile araştırmış ve dört farklı kârlılık ölçüsünün sermaye yoğunluğundan, ölçek ekonomisinden, sektör büyüme oranından ve verimlilik düzeyinden pozitif, sektördeki yabancı sahiplik oranından ise negatif etkilendiğini bulmuştur. Leiponen (2000), Finlandiya'dan 209 imalat sanayi işletmesinin 1985-1993 yıllarına ait verilerini dinamik panel veri analizinde kullandığı çalışmasında sermaye yoğunluğunun, pazar payının ve inovasyon sayısının net kâr marjını pozitif olarak etkilediği sonucuna ulaşmıştır. Goddard, Tavakoli ve Wilson (2005) ise Belçika, Fransa, İtalya, İspanya ve Birleşik Krallık'tan 5.000'in üzerinde imalat sanayi işletmesinin 1993-2001 yıllarına ait verilerini kullanarak kârlılık oranını etkileyen değişkenleri dinamik panel veri analizi ile incelemişlerdir. Çalışmanın sonuçları; aktif kârlılık oranının bir dönem gecikmeli değerinden, cari orandan ve pazar payından pozitif, işletme büyüklüğünden ve borçluluk düzeyinden de negatif olarak etkilendiğini ortaya koymuştur.

\section{EKONOMETRIK ANALIZ}

\subsection{Veri Seti ve Değişkenler}

İmalat sanayi sektöründe kârııı̆̆ı etkileyen işletme düzeyindeki değişkenleri tespit etmeyi amaçlayan bu ekonometrik analizde, TCMB tarafından hazırlanan sektör bilançoları verilerinden yararlanılmıştır. TCMB, reel sektörde faaliyet gösteren yaklaşık on bin işletmeye ait sektör bazında ayrıntılı finansal bilgileri
1996 yılından itibaren düzenli olarak her yıl kamuoyuyla paylaşmaktadır. TCMB'nin bu çalışmasına konu işletmeler yıldan yıla farklılaşabilmekle beraber üç yıllık sürekli bilanço ve gelir tablosu bulunan işletmelere ait finansal veriler toplulaştırılarak sektör bilançoları, sektör gelir tabloları, sektörlere ilişkin finansal oranlar, sektör fon akım tabloları hazırlanmakta ve sektörlere özel diğer birtakım bilgiler de özetlenmektedir. 2014'teki çalışmada bilgileri yer alan 10.376 işletmenin toplam çalışan sayısı 2 milyonu geçmekte ve aynı yıldaki çalışmada Borsa İstanbul'a kote 123 işletmenin ve İstanbul Sanayi Odası'nın en büyük 1.000 sanayi kuruluşu araştırmasındaki 626 işletmenin verileri de yer almaktadır.

Çalışmanın veri setini oluşturan TCMB sektör bilançoları kapsamında süreklilik göstermeyen imalat sanayi alt sektörleri veri setinden çıkarılmış ve yine bazı alt sektörlerdeki veri kısıtları nedeniyle ilgili sektörlerden birkaçı birleştirilmiş ve birleştirilen sektörlere ilişkin oran ve büyüklükler tarafımızdan hesaplanmıştır. Sonuçta imalat sanayi sektöründe yer alan 12 alt sektör belirlenmiş ve her bir sektör bir birim olarak kabul edilerek panel veri seti oluşturulmuştur. Ekonometrik analize konu olan imalat sanayi alt sektörlerine ait 1996-2015 yılları arasında 20 döneme ilişkin yıllık veriler TCMB'nin web sitesinden alınmıştır. 2015 itibariyle verilerinden yararlanılan 2.874 işletmenin imalat sanayi alt sektörlerine göre dağılımı aşağıdaki gibidir:

Tablo 1: Veri Setindeki İşletmelerin Sektörel Dağııımı

\begin{tabular}{|l|c|}
\hline Sektör & İşletme sayısı \\
\hline Gıda ürünleri ve içecek sanayi & 545 \\
\hline Tekstil ürünleri sanayi & 446 \\
\hline Giyim eşyaları sanayi & 242 \\
\hline Deri ve ilgili ürünler sanayi & 50 \\
\hline Ağaç ve ağaç ürünleri sanayi & 63 \\
\hline Kâğı ürünleri ve basım sanayi & 118 \\
\hline Kimya ürünleri ve eczacılık sanayi & 184 \\
\hline Kauçuk ve plastik ürünler sanayi & 224 \\
\hline Metalik olmayan mineral ürünler sanayi & 329 \\
\hline Ana metal ve fabrikasyon metal ürünleri sanayi & 249 \\
\hline Motorlu araçlar ve diğer ulaşım araçları sanayi & 187 \\
\hline Makine ve ekipman sanayi & 237 \\
\hline Toplam & $\mathbf{2 . 8 7 4}$ \\
\hline
\end{tabular}

Kaynak: www.tcmb.gov.tr 
Üç bine yakın işletmenin verileriyle oluşturulan sektörel bilanço ve gelir tabloları aracılığıyla imalat sanayi sektöründe kârlılığın belirleyicilerini tespit etmeyi amaçlayan bu ekonometrik analizde kullanılmak üzere, daha önceki benzer çalışmalarda sıklıkla yer alan 1 bağımlı değişken ve 5 bağımsız değişken seçilmiştir. Kârlılığı etkilemesi beklenen bağımsız değişkenler; likiditeyi, finansal yapıyı, varlık yapısını, alacak yönetimini ve büyüklüğü temsilen çalışmaya dahil edilmiştir. Çalışmada kullanılan bağımlı ve bağımsız değişkenler şunlardır:

\section{Bağımlı değişken $\rightarrow$}

Kârlılık: Aktif Kârlılık Oranı (AKO): Oran, işletmenin kaynaklarını ne ölçüde kârlı kullandığını gösterir. Net kâr, faiz ve vergi öncesi kar (FVÖK) ve vergi sonrası faaliyet kârının varlıklara bölünmesiyle farklı şekillerde hesaplanabilen ve FVÖK ile hesaplandığında ekonomik rantabilite olarak da adlandırılan aktif kârlılık oranı için aşağıdaki eşitlik kullanıımıştır (Akgüç, 1998: 68):

$$
\text { Aktif Kârlılık Oranı }=\frac{\text { FVÖK (Vergiden Önceki Kâr }+ \text { Fin. Gid. })}{\text { Varlıklar }}
$$

Ekonomik rantabilite, sermaye yapısından ve vergi uygulamalarından bağımsız olarak işletmenin ana faaliyetlerinin etkinliğini ve kârlılığını ifade eder. Aynı oran, farklı finansman stratejilerine sahip olan ve farklı vergi düzenlemelerine tabi olan işletmelerin etkinliklerinin karşılaştırılmasını da sağlar. Oranın karşılaştırmalı analizlerde kullanımı, yüksek finansman ve vergi giderlerine sahip fakat sermayesini yüksek verimlilikle kullanan işletmelerin daha az kârlı görünmesinin önüne geçer.

\section{Bağımsız değişkenler $\rightarrow$}

Likidite: Cari Oran (CO): Oran; işletmenin genel likidite durumunu yansıtarak net çalışma sermayesinin yeterliliğini ortaya koyar. Kısa vadeli borçların ödenmesi veya beklenmedik yükümlülüklerin zamanında karşılanabilmesi için ve dönen varlıklarda ortaya çıkabilecek değer kayıplarına önlem olarak cari oranın 1'den büyük olması beklenir. Cari oran dönen varlıkların kısa vadeli yabancı kaynaklara oranlanması ile bulunur (Akdoğan ve Tenker, 2007: 645-646).

$$
\text { Cari Oran }=\frac{\text { Dönen Varlıklar }}{\text { Kısa Vadeli Yabancı Kaynaklar }}
$$

Smith'e (1980) göre çalışma sermayesi yönetimi işletmenin kârlılığını, riskini ve değerini etkileyebilmektedir. Eljelly (2004) de, etkin çalışma sermayesi yönetiminin işletmenin günlük faaliyetlerini sürdürebilmek ve vadesi gelen borçlarını ödeyebilmek için gerekli likiditenin sağlanması açısından önemine vurgu yapmış ve işletmenin değerinin artırılabilmesi için likidite ve kârlılık arasında rasyonel bir dengenin kurulması gerektiğini belirtmiştir. Nazir ve Afza'ya (2009) göre dönen varlıklara gereğinden az yapılan yatırım likidite krizine ve kârlı yatırım fırsatlarının kaçırılmasına neden olabilirken, gereğinden fazla yatırım da kısa vadeli yatııımların getirisini düşürerek kârlılığı azaltabilmektedir. Shin ve Soenen (1998) ise

$$
\text { Kaldıraç Oranı }=\frac{\text { Yabancı Kaynaklar }}{\text { Varlıklar }}
$$

Finansal yapı ve kârlılık ilişkisi özellikle sermaye yapısı teorilerinde kendine yer bulmaktadır. Bu teorilerden sermaye piyasalarında tam rekabetin olduğu varsayımına dayanan Modigliani ve Miller'in (1958) geliştirdiği ilk modern sermaye yapısı teorisine dönen varlıkların belirli bir seviyeye dek azaltılmasının kârlılı̆̆ artırabileceğini savunmuştur. Bu bağlamda likidite ve risk arasında optimal bir denge kurarak dönen varlıkları ve kısa vadeli yabancı kaynakları dikkate alan etkin likidite yönetimi sağlayan işletmeler kârıııklarını da artırabilecektir.

Finansal Yapı: Kaldıraç Oranı (KO): Oran, varlıkların ne kadarının yabancı kaynaklarla finanse edildiğini ifade eder. Kaldıraç oranının yüksek olması kreditörler için olası bir iflas durumunda emniyet payının dar olduğu anlamına gelir. Bu oranın giderek artması işletmenin finansal riskini de artırır (Van Horne ve Wachowicz, 2008: 140-141).

(M\&M Theory) göre işletmelerde varlıkların hangi tür kaynaklarla finanse edildiğinin işletme değeri açısından bir önemi yoktur, işletmeler kâr elde etme güçlerine bağlı olarak piyasa değerlerini artırabilir. Modigliani ve Miller 1963'te yayımladıkları çalışma- 
larında ise düzeltme yaparak borcun sağladığı vergi kalkanı da teorilerine dahil etmişler ve yabancı kaynak kullanımının belirli bir noktaya kadar işletmenin kârlııı̆ını ve değerini artırabileceğini vurgulamışlardır. Kraus ve Litzenberger (1973) ve Myers'in (1984) savunucuları arasında yer aldığı Dengeleme Teorisi'ne (Trade-off Theory) göre ise işletmeler vergi kalkanının marjinal değerinin borçlanma düzeyinin artmasıyla ilişkili ve Jensen ve Meckling'in (1976) değindiği temsil maliyetlerini de içeren finansal maliyetlerin bugünkü değerine eşit olduğu noktaya dek borçlanabilecek ve özellikle düşük riskli işletmeler bu şekilde kârlıklarını artırabileceklerdir. Donaldson'ın (1961) çalışmasına dayanan Finansman Hiyerarşisi Teorisi (Pecking Order Theory) de temelde işletmelerin finansman ihtiyaçları için öncelikle iç kaynaklara yöneldiğini savunmaktadır. Myers (1984), teori kapsamında ucuz iç kaynakların yetmediği durumlarda işletmelerin daha düşük maliyet nedeniyle ilk önce borçlanarak en son olarak da dış kaynaklardan sağlanan özkaynağa yöneldiğini öne sürmektedir. Myers ve Majluf da (1984) dış kaynaklar açısından borç finansmanının göreceli daha az riskli olduğunu ve sermaye piyasalarından sağlanan özkaynak finansmanında bilgi asimetrisi problemlerinin daha yoğun yaşandığını savunmaktadır. Teoriye göre yatırımların finansmanında yüksek oranda borç kullanan işletmelerin kârlılıkları düşebilecektir.
İşletme değerini ve kârlııı̆ını maksimize edecek optimal sermaye yapısına yönelik arayışlar devam etmekle beraber Baker ve Wurgler'in (2002) modellediği ve işletmelerin sermaye yapılarını piyasadaki dinamik hisse senedi fiyat değişimlerine göre oluşturduğunu savunan Piyasa Zamanlama Teorisi de (Market Timing Theory) güncelliğini korumaktadır.

Varlık Yapısı: Maddi Duran Varlıklar/Varlıklar Oranı (MDV/A): Maddi duran varlık oranının yüksek olması işletmeleri kârlılık açısından hem pozitif hem de negatif olarak etkileyebilmektedir. İşletmeler bu varlıkları teminat olarak gösterip çeşitli ucuz finansman alternatiflerinden yararlanma firsatı bularak kârlı yatırım fırsatlarıyla kârılıklarını artırabilirken diğer taraftan varlıkların düşük verimlilik ve kapasiteyle işletilmesi kârlılık düzeyini azaltıcı etkide bulunabilmektedir.

Alacak Yönetimi: Alacak Devir Hızı (ADH): Iş̧letmelerin kredili satışlarından doğan ticari alacakların yönetimi, çalışma sermayesi yönetiminin önemli bir parçası olmakla beraber alacaklara bağlanan fonlardan en yüksek getiriyi sağlamayı hedefler. Deloof (2003) alacak devir hızını artırıp alacakların tahsil süresini makul bir seviyeye dek azaltan işletmelerin kârlııklarını da artıracaklarını belirtmiştir.

\section{Alacak Devir Hızı $=\frac{\text { Net Satışlar }}{\text { Kısa ve Uzun Vadeli Ticari Alacaklar }}$}

Büyüklük: (LRA): Büyüklük, ağırlıklı olarak toplam aktifler ve toplam satışlar ile ifade edilmektedir. Araştırmada işletme büyüklüğünü temsil etmesi için aktif toplamları dikkate alınmıştır. Aktif toplamları tüketici fiyat endeksi (TÜFE) (1994=100) kullanılarak reel hale getirilmiş ve ilgili tutarların doğal logaritmaları hesaplanmıştır. Gschwandtner'e (2005) göre büyük işletmeler; faaliyetlerini ve ürünlerini çeşitlendirebilmek için daha yüksek kapasiteye ve piyasadaki potansiyel rakiplerle rekabet edebilmek adına daha fazla güce sahiptir ve işletmeler büyüdükçe ölçek ekonomisinin avantajlarından daha kolay yararlanmaktadır.

Panel veri setine ilişkin tanımlayıcı istatistikler de aşağıdaki gibidir:

Tablo 2: Değişkenlere Illişkin Tanımlayıcı İstatistikler

\begin{tabular}{|c|c|c|c|c|c|c|}
\hline & AKO (\%) & CO (\%) & KO (\%) & MDV/A (\%) & ADH & LRA \\
\hline Ortalama & 11,25371 & 142,9684 & 57,98761 & 30,66326 & 5,067722 & 11,23132 \\
\hline Medyan & 10,02288 & 141,6034 & 58,04526 & 30,12037 & 4,821957 & 11,46933 \\
\hline Maksimum & 28,93390 & 199,7378 & 80,98570 & 47,96032 & 9,329000 & 12,96857 \\
\hline Minimum & $-0,456287$ & 81,12874 & 30,12545 & 12,78846 & 2,254847 & 8,521572 \\
\hline Std. Sapma & 5,136701 & 19,98158 & 8,874222 & 7,842676 & 1,413952 & 1,082448 \\
\hline Gözlem Sayısı & 240 & 240 & 240 & 240 & 240 & 240 \\
\hline
\end{tabular}


Tanımlayıcı istatistiklere göre imalat sanayi sektöründe varlıklar genel olarak kârlı kullanılmaktadır. Dönen varlıklar kısa vadeli yabancı kaynakların yaklaşık 1,5 katıyken; varlıkların \%58'i yabancı kaynaklar, \%42'si ise özkaynaklar ile finanse edilmektedir. Maddi duran varlıkların toplam varlıklar içindeki ortalama payının göreceli yüksek olması, imalat sanayi sektörünün yapısına uygunluk göstermektedir. Diğer taraftan sektörde alacaklar ortalama 72 günde tahsil edilmektedir. Değişkenlerin yüksek standart sapmalara sahip olmaması da alt sektörlerin birbirine yakın finansal oranlara sahip olduğunu ortaya koymaktadır.

\subsection{Yöntem ve Analiz Sonuçları}

Finansal ekonometrik analizlerde farklı veri türleri kullanılmakta ve analiz edilen veri setinin özelliklerine bağlı olarak da farklı analiz yöntemlerinden yararlanılmaktadır. Ekonometrik analizlere konu olan veriler; yatay kesit verileri, zaman serileri ve yatay kesit verileri ile zaman serilerinin birleşimiyle ortaya çıkan ve zaman ve birim boyutunda bilgi içeren panel veriler olmak üzere üç grup olarak sınıflandırılmaktadır. Zaman boyutuna sahip yatay kesit birimlerine ait verilerin kullanılarak regresyon modellerinin kurulması ve yorumlanması, panel veri analizi olarak adlandırılır. Panel veri setinde yatay kesit birimlerinin zaman boyutunda eksik dönemler mevcutsa dengeli olmayan panel, zaman boyutunda eksik dönemler mevcut değilse dengeli panel söz konusudur (Asteriou ve Hall, 2007: 344-345). Panel veri analizinde kullanılan panel veriler, yatay kesit verilerine ve zaman serilerine birçok açıdan üstünlük sağlar. Panel veri; yatay kesit verilerine ve zaman serilerine göre daha fazla örneklem çeşitliliği ve serbestlik derecesi içerdiğinden daha doğru parametre tahminleri sağlar, karmaşık modellerin ve davranışsal hipotezlerin oluşturulmasına ve test edilmesine imkân verir, zamanlar arası ilişkileri ve birimlerin spesifik bilgilerini içerdiğinden gözlemlenemeyen değişkenlerin daha kolay kontrol edilmesini olanaklı kılar, ekonomik davranışların dinamik yapısını ortaya çıkarır, farklı birimlere ait verileri bir araya getirerek daha tutarlı tahminlerin yapılmasını sağlar, birimlerin zaman boyutunda bilgilerini barındırdığından ve heterojeniteden daha çok homojenitenin araştırılmasına yardımcı olduğundan benzer özelliklere sahip birimlere ilişkin daha uygun analiz sonuçlarına ulaşılmasına yardımcı olur (Hsiao, 2007: 2-6).

Panel veri analizinde, sabit etkiler (fixed effects) veya tesadüfi etkiler (random effects) modellerin- den yararlanılır. Sabit etkiler modeli aşağıdaki gibi gösterilir (Gujarati, 2003: 642):

$Y_{\text {it }=} \alpha_{i}+\beta_{2} X_{2 i t}+\beta_{3} X_{3 i t}+\varepsilon_{\text {it }}$ (Tek yönlü sabit etkiler modeli)

Sabit etkiler modelinde $Y_{i t}$ bağımlı değişkeni, $X_{2 i t}$ ve $X_{3 i t}$ bağımsız değişkenleri, $a_{i}$ birimden birime değişebilen sabiti, $\beta_{2}$ ve $\beta_{3}$ bağımsız değişkenlerin eğim katsayılarını, $\varepsilon_{\text {it }}$ hata terimini ifade ederken; modeldeki birimlerden her birini, tise zamanı göstermektedir. Sabit etkiler modelinde yatay kesit birimleri arasındaki spesifik bireysel özellikleri temsil eden sabit, birimler arasında farklııı gösterebilirken; her birimin sabiti zamana bağlı olarak değişmez. Bu modelde bağımsız değişkenlerin eğim katsayılarının yatay kesit ve zaman boyutuna göre değişmediği kabul edilir. Bu haliyle sadece birim etkisini dikkate alan ve tek yönlü (sabit birim etkileri modeli) olan modele zaman etkisi de dahil edilirse, $\lambda_{t}$ zamandan zamana değişebilen sabiti ifade etmek üzere model aşağıdaki gibi iki yönlü sabit etkiler modeli haline gelir (Gujarati, 2003: 642-644):

$Y_{i t}=a_{i}+\beta_{2} X_{2 i t}+\beta_{3} X_{3 i t}+\varepsilon_{i t}+\lambda_{t}$ (iki yönlü sabit etkiler modeli)

Panel veri analizinde kullanılan diğer bir model ise tesadüfi etkiler modelidir. Bu model aşağıdaki gibi ifade edilir (Gujarati, 2003: 647):

$Y_{i t}=a+\beta_{2} X_{2 i t}+\beta_{3} X_{3 i t}+w_{i t}\left(\mu_{i}+\varepsilon_{i t}\right)$ (Tek yönlü tesadüfi etkiler modeli)

Tesadüfi etkiler modelinde birimlerin ortak sabitleri olduğu varsayılır ve birimlere özgü farklılıklar hata terimleri ile ifade edilir. $\mu_{i}$ birimlere özgü sıfır ortalamalı ve sabit varyanslı gözlemlenemeyen tesadüfi hata terimiyken, $\varepsilon_{\text {it }}$ zaman serisi ile yatay kesitin birleşimi sonucu ortaya çıkan hata terimi, $\mathrm{w}_{\mathrm{it}}$ ise bileşik hata terimidir. Tesadüfi etkiler modelinde a yatay kesit sabitlerinin ortalamasını, $\mu_{i}$ ise birimlere ilişkin sabitlerin ortalama sabitten tesadüfi sapmasını ifade eder (Gujarati, 2003: 647-648). Bu haliyle sadece birim etkisini dikkate alan ve tek yönlü (tesadüfi birim etkileri modeli) olan modele $\lambda_{t}$ ile ifade edilen gözlemlenemeyen zaman etkisi de dahil edilirse, model aşağıdaki gibi iki yönlü tesadüfi etkiler modeli haline gelir (Baltagi, 2005: 33-35):

$Y_{i t}=a+\beta_{2} X_{2 i t}+\beta_{3} X_{3 i t}+w_{i t}\left(\mu_{i}+\varepsilon_{i t}+\lambda_{t}\right)$ (iki yönlü tesadüfi etkiler modeli) 
Çalışmada aktif kârlılık oranının bağımlı değişken olarak kullanılacağı uygun panel regresyon modeli kurulmadan önce modelde yer alan bağımsız değişkenler arasında doğrusal bir ilişki mevcut olduğunda ortaya çıkan ve parametre tahminlerinde hatalı sonuçlara yol açabilen çoklu bağlantı (multicollinearity) sorunun olup olmadığına bakılması gerekmektedir. Çoklu bağlantının varlığı, bağımsız değişkenlerin varyans şişirme faktörlerine (Variance Inflation Factors-VIF) bakılarak tespit edilebilmektedir. Varyans şişirme faktör değerleri 10'un üstünde olan bağımsız değişkenlerin yer aldığı modellerde çoklu bağlantı sorunu ortaya çıkmaktadır (Wooldridge, 2012: 95-98). Varyans şişirme faktör değerlerinin' $\mathrm{CO}, \mathrm{KO}, \mathrm{MDV} / \mathrm{A}, \mathrm{ADH}$ ve LRA değişkenleri için sırasıyla $2,46,2,53,1,66,1,23$ ve 1,20 olarak tespit edilmesi; bağımsız değişkenler arasında çoklu bağlantı sorununun olmadığını göstermektedir.

Panel veri analizi, yatay kesit ve zaman serilerine karşı birçok avantaj taşımakla beraber yapısı gereği zaman serisi verileri içerdiğinden zaman serilerinde karşılaşılan sorunları da beraberinde getirebilmektedir. Bu özelliklerden biri de panel veri setinde durağan dışılıkla diğer bir ifadeyle birim kökün varlığıyla karşılaşabilme olasılığıdır. Ortalaması, varyansı ve otokovaryansı zamandan bağımsız olarak sabit kalan bir zaman serisi durağan olarak kabul edilir. Durağanlık koşullarını sağlamayan ve durağan dışı zaman serileri ise birim köke sahiptir (Asteriou ve Hall, 2007: 231). Durağan dışılık özellikle iktisadi ve finansal zaman serilerinde sıklıkla görülmektedir.
Granger ve Newbold (1974), ekonometrik analizlere durağan olmayan verilerin dahil edilmesinin sahte regresyon problemine neden olabileceğini belirtmişlerdir. Sahte regresyonda yüksek açıklama gücüne ve anlamlı değerlere ulaşılsa bile model parametrelerini yorumlamak anlamsız hale gelmektedir. Sahte regresyon sorunundan kaçınmak için model tahmini yapılmadan önce serilerin durağan olup olmadığının tespit edilmesi gerekir. Literatürde panel veri setlerinde kullanılmak üzere birden fazla birim kök testi geliştirilmiştir. Panel birim kök testlerinden bireysel testler ve ortak birim kök testleri, verilerin durağanlığının kontrolü için sıklıkla tercih edilmektedir. En yaygın kullanılan ortak panel birim kök testleri Levin, Lin, Chu (2002) ve Breitung (2000), tekil panel birim kök testleri ise Maddala ve Wu (1999) ve Choi (2001) tarafından geliştirilen Fisher tabanlı Artırılmış Dickey-Fuller (ADF) ve Phillips-Perron (PP) testleri ve Im, Pesaran, Shin (2003) testidir. Serilerde birim kökün varlığını sınamak amacıyla, Levin, Lin, Chu (LLC), Im, Pesaran, Shin (IPS) ve Fisher tabanlı Artırılmış Dickey-Fuller (ADF) panel birim kök testleri kullanılmıştır. Her üç test için de aşağıdaki hipotezler kurulmuştur:

\section{$\mathrm{H}_{0}$ : Seri durağan değildir (Birim kök içerir) \\ $\mathrm{H}_{1}$ : Seri durağandır (Birim kök içermez)}

Optimal gecikme düzeyi için Schwarz kriteri ve Newey-West bant genişliği için Bartlett Kernel'in kullanıldığı ve maksimum gecikme uzunluğunun 1 olarak alındığı birim kök testlerinin sonuçları düzeyde sabitli ve sabitli-trendli olarak şu şekildedir²:

Tablo 3: Birim Kök Test Sonuçları (Düzey)

\begin{tabular}{|c|c|c|c|c|c|c|}
\hline \multirow{2}{*}{} & \multicolumn{2}{|c|}{ LLC (p-değeri) } & \multicolumn{2}{c|}{ IPS (p-değeri) } & \multicolumn{2}{c|}{ ADF (p-değeri) } \\
\cline { 2 - 7 } & Sabitli & Sabitli-Trendli & Sabitli & Sabitli-Trendli & Sabitli & Sabitli-Trendli \\
\hline AKO & 0,0000 & 0,0000 & 0,0003 & 0,0007 & 0,0019 & 0,0021 \\
\hline CO & 0,0139 & 0,2426 & 0,0616 & 0,5962 & 0,1559 & 0,6452 \\
\hline KO & 0,6089 & 0,9930 & 0,4339 & 0,9977 & 0,7696 & 0,9989 \\
\hline MDV/A & 0,5674 & 0,0512 & 0,6482 & 0,5209 & 0,6653 & 0,7539 \\
\hline ADH & 0,0307 & 0,0007 & 0,0434 & 0,0230 & 0,0758 & 0,0668 \\
\hline LRA & 0,7236 & 0,2582 & 0,9650 & 0,1048 & 0,8270 & 0,1750 \\
\hline
\end{tabular}

Veri setinde $A K O$ ve $A D H$ değişkenleri \%10 anlamlılık seviyesinde düzeyde durağanken, düzeyde durağan olmayan $\mathrm{CO}, \mathrm{KO}, \mathrm{MDV} / \mathrm{A}$ ve LRA değişkenleri 1. farkları alınarak durağanlaştııımıştır:

\footnotetext{
1Varyans şişirme faktör değerleri, Stata 12 ekonometrik analiz programı kullanılarak hesaplanmıştır.

${ }^{2}$ Panel birim kök testleri Eviews 9 ekonometrik analiz programı kullanılarak yapılmıştır, çalışmada yapılan diğer analizlerde de bu programdan yararlanılmıştır.
} 
Tablo 4: Birim Kök Test Sonuçları (1. Fark)

\begin{tabular}{|c|c|c|c|c|c|c|}
\hline \multirow{2}{*}{} & \multicolumn{2}{|c|}{ LLC (p-değeri) } & \multicolumn{2}{c|}{ IPS (p-değeri) } & \multicolumn{2}{c|}{ ADF (p-değeri) } \\
\cline { 2 - 7 } & Sabitli & Sabitli-Trendli & Sabitli & Sabitli-Trendli & Sabitli & Sabitli-Trendli \\
\hline CO & 0,0000 & 0,0000 & 0,0000 & 0,0000 & 0,0000 & 0,0000 \\
\hline KO & 0,0000 & 0,0000 & 0,0000 & 0,0000 & 0,0000 & 0,0000 \\
\hline MDV/A & 0,0000 & 0,0000 & 0,0000 & 0,0000 & 0,0000 & 0,0000 \\
\hline LRA & 0,0000 & 0,0000 & 0,0000 & 0,0000 & 0,0000 & 0,0000 \\
\hline
\end{tabular}

Regresyonlarda birim köke sahip olmayan serilerin kullanılması gereğinden hareketle çalışmanın devamında tahmin edilen panel veri modelinde AKO ve $A D H$ değişkenlerinin düzey değerleri; $C O, K O$, $M D V / A$ ve LRA değişkenlerinin ise durağan 1. farkları kullanılmıştır.

Panel veri setlerine ilişkin hangi regresyon modelinin daha uygun olduğunu tespit etmek için çeşitli testler yapilır. Bu testlerden ilki panel veri setinin yatay kesit ve zaman boyutunu ihmal eden ve klasik En Küçük Kareler (EKK) yöntemi ile tahmin edilen havuzlanmış regresyon (pooled regression) ile sabit etkiler regresyon modeli arasında tercih yapmak için kullanılan ve $\mathrm{F}$ istatistiğine dayanan olasılık oran (likelihood ratio) testidir. Bu testte $\mathrm{H}_{0}$ sıfir hipotezleri, sırasıyla "birimlere bağlı sabit etki yoktur", "zamanlara bağlı sabit etki yoktur" ve "hem birimlere hem de zamanlara bağlı sabit etki yoktur" şeklinde kurulur (Greene, 2003: 289; Brooks, 2008: 508). Panel veri modeli için elde edilen olasılık oran test sonuçları aşağıdaki gibidir:

Tablo 5: Olasılık Oran Test Sonuçları

\begin{tabular}{|c|c|c|c|}
\hline & İstatistik & $\begin{array}{c}\text { Serbestlik } \\
\text { derecesi }\end{array}$ & p-değeri \\
\hline $\mathrm{F}_{\text {birim }}$ & 10,425234 & 11,204 & 0,0000 \\
\hline $\mathrm{F}_{\text {zaman }}$ & 14,578368 & 19,204 & 0,0000 \\
\hline $\mathrm{F}_{\text {birim-zaman }}$ & 21,675135 & 30,204 & 0,0000 \\
\hline
\end{tabular}

Test sonuçlarına göre $\mathrm{H}_{0}$ sıfır hipotezlerinin \%1 anlamlıık düzeyinde reddedilmesi; sabit etkiler modelinin havuzlanmış regresyon modeline tercih edilmesi ve ayrıca sabit etkiler modelinin seçilmesi durumunda sabit etkilerin hem birim hem de zaman boyutunda dikkate alınması gerektiğini göstermektedir. Diğer ilgili testlerden Lagrange Çarpanı (Lagrange Multiplier) testi ise panel veri setinin yatay kesit ve zaman boyutunu ihmal eden ve klasik En Küçük Kareler (EKK) yöntemi ile tahmin edilen havuzlanmış regresyon ile tesadüfi etkiler regresyon modeli arasında tercih yapmak için kullanılır. Bu testte tesadüfi etkilerin birim boyutunda, zaman boyutunda ve hem birim hem de zaman boyutunda anlamsızlığı $\mathrm{H}_{0}$ ile ifade edilir (Torres-Reyna, 2007: 32). Tesadüfi etkilerin anlamlılığı için çift kuyruklu Breusch-Pagan (1980) ve tek kuyruklu Honda (1985) testlerinden yararlanılmıştır:

Tablo 6: Lagrange Çarpanı Test Sonuçları

\begin{tabular}{|l|l|l|l|}
\hline & Birim & Zaman & $\begin{array}{l}\text { Birim- } \\
\text { Zaman }\end{array}$ \\
\hline $\begin{array}{l}\text { Breusch-Pagan } \\
\text { Test istatistiği } \\
\text { (p-değeri) }\end{array}$ & $\begin{array}{l}78,60688 \\
(0,0000)\end{array}$ & $\begin{array}{l}201,0938 \\
(0,0000)\end{array}$ & $\begin{array}{l}279,7007 \\
(0,0000)\end{array}$ \\
\hline $\begin{array}{l}\text { Honda } \\
\begin{array}{l}\text { Test istatistiği } \\
\text { (p-değeri) }\end{array}\end{array}$ & $\begin{array}{l}8,866052 \\
(0,0000)\end{array}$ & $\begin{array}{l}14,18076 \\
(0,0000)\end{array}$ & $\begin{array}{l}16,29655 \\
(0,0000)\end{array}$ \\
\hline
\end{tabular}

Her iki testin sonuçlarına göre $\mathrm{H}_{0}$ sıfır hipotezlerinin \%1 anlamlılık düzeyinde kabul edilmemesi; tesadüfi etkiler modelinin havuzlanmış regresyon modeline tercih edilmesi ve ayrıca tesadüfi etkiler modelinin seçilmesi durumunda tesadüfi etkilerin hem birim hem de zaman boyutunda dikkate alınması gerektiğini ifade etmektedir. Model seçiminde kullanılan bir diğer test de Hausman (1978) testidir. Hausman testinin sonucuna göre sabit etkiler modelinin mi yoksa tesadüfi etkiler modelinin mi daha uygun olduğuna karar verilir. Bu testte $\mathrm{H}_{0}$ sıfır hipotezi, "tesadüfi etkiler ve açıklayıcı değişkenler arasında korelasyon yoktur" şeklinde kurulur. Panel veri modeli için elde edilen test sonuçları aşağıdaki gibidir:

Tablo 7: Hausman Testi Sonuçları

\begin{tabular}{|c|c|c|c|}
\hline & Ki-kare istatistiği & $\begin{array}{l}\text { Serbestlik } \\
\text { Derecesi }\end{array}$ & p-değeri \\
\hline Birim & 51,777454 & 5 & 0,0000 \\
\hline Zaman & 71,505614 & 5 & 0,0000 \\
\hline
\end{tabular}


Hausman testi sonuçlarına göre \%1 anlamlılık düzeyinde $\mathrm{H}_{0}$ sıfır hipotezi hem birim hem de zaman boyutunda reddedilmiştir. Sıfır hipotezinin kabul edilmemesi, tesadüfi etkiler ve açıklayıcı değişkenler arasında korelasyonun bulunduğunu ve bu durumda birim ve zaman boyutlarında sabit etkilerin dikkate alınacağı modelin tahmin edilmesinin daha etkin olacağını göstermektedir. Olasılık oran sonuçları da dikkate alındığında tahmin edilen sabit etkiler modelinde hem birim etkisi hem de zaman etkisinin yer alması gerekmektedir.

Zaman serileri ve yatay kesit analizlerinde olduğu gibi panel veri analizlerinde de otokorelasyon (auto- correlation) önemli bir sorundur. Otokorelasyona ek olarak panel veri regresyon modellerinde hata terimlerinin varyansının sabit olmadığı durumda ortaya çıkan değişen varyans (heteroscedasticity) sorunuyla da karşılaşılabilmektedir (Gujarati, 2003: 68-70). Çalışmada muhtemel otokorelasyon ve değişen varyans sorunlarının varlığında robust (dirençli) standart hatalar ve tutarlı analiz sonuçları elde etmek amacıyla White period tahmincisi kullanılmıştır (Reed ve Ye, 2011: 989). Analizi yapılan panel veri seti dengeli olmakla beraber tahmin edilen iki yönlü sabit etkiler modeli ve model tahmin sonuçları aşağıdaki gibidir³:

$$
\mathrm{AKO}_{\mathrm{it}}=a_{\mathrm{i}}+\beta_{1} \mathrm{CO}_{\mathrm{it}}+\beta_{2} \mathrm{KO}_{\mathrm{it}}+\beta_{3}(\mathrm{MDV} / \mathrm{A})_{\mathrm{it}}+\beta_{4} \mathrm{ADH}_{\mathrm{it}}+\beta_{5} \mathrm{LRA}_{\mathrm{it}}+\varepsilon_{\mathrm{it}}+\lambda_{\mathrm{t}}
$$

Tablo 8: Iki Yönlü Sabit Etkiler Modeli Tahmin Sonuçları ${ }^{4}$

\begin{tabular}{|c|c|c|c|c|}
\hline & \multicolumn{4}{|c|}{ Bağımlı Değişken: AKO } \\
\hline Bağımsız Değişkenler & Katsayı & Standart hata & t-istatistiği & p-değeri \\
\hline CO & $-0,001873$ & 0,012947 & $-0,144702$ & $\mathbf{0 , 8 8 5 1}$ \\
\hline KO & $-0,123142$ & 0,060000 & $-2,052357$ & $\mathbf{0 , 0 4 1 5}$ \\
\hline MDV/A & $-0,216875$ & 0,068074 & $-3,185843$ & $\mathbf{0 , 0 0 1 7}$ \\
\hline ADH & 0,588888 & 0,284936 & 2,066742 & $\mathbf{0 , 0 4 0 1}$ \\
\hline LRA & 5,661685 & 1,258001 & 4,500542 & $\mathbf{0 , 0 0 0 0}$ \\
\hline Gözlem sayısı: 228 & F-istatistiği (p-değeri): $16,776(0,0000)$ & \multicolumn{3}{|c}{ Düz. $R^{2}: 0,702642$} \\
\hline
\end{tabular}

Aktif kârlılık oranının bağımlı değişken olarak kullanıldığı model tahmininin F-istatistiğine bakılarak \%1 anlamlılık düzeyinde genel olarak anlamlı olduğu ve bağımlı değişkendeki değişimin yaklaşık \%70'inin bağımsız değişkenler tarafından açıklandığı görülmektedir. Model tahmin sonuçlarına göre bağımsız değişkenlerden $K O, M D V / A, A D H$ ve LRA değişkenlerinin katsayılarının anlamsız olduğunu ifade eden $\mathrm{H}_{0}$ sıfır hipotezleri \%5 anlamlılık düzeyinde reddedilirken, CO bağımsız değişkeni ve bağımlı değişken arasında anlamlı bir istatistiksel ilişki bulunamamıştır. Değişkenlerden KO ve MDV/A aktif kârlılık oranını negatif olarak etkilerken; ADH ve LRA değişkenleri ise aktif kârlııı oranını pozitif olarak etkilemektedir.

Kaldıraç oranının kârlıı̆ı negatif olarak etkilemesi; Myers (1984) ve Myers ve Majluf'un (1984) öne sürdüğü ve yatırımların finansmanında yüksek oranda borç kullanan işletmelerin kârlılıklarının düşe- bileceğini savunan Finansman Hiyerarşisi Teorisi'ni imalat sanayi özelinde yabancı kaynak-kârlılık ilişkisi açısından desteklemektedir. Ülkemiz imalat sanayi sektöründe aktiflerin finansmanında yüksek oranda yabancı kaynak kullanımıyla artan finansal riskler düşük kârlılık oranlarına neden olmaktadır. Maddi duran varlıkların toplam varlıklara oranıla aktif kârlılık oranı arasındaki negatif ilişki de maddi duran varlıkların düşük verimlilik ve kapasiteyle işletildiğini diğer bir ifadeyle bu varlıklara gereğinden fazla yatırım yapıldığını göstermektedir. TCMB verilerine göre 2015 yılı imalat sanayi kapasite kullanım oranının yaklaşık \%75 olması, sektördeki düşük kapasite kullanımını teyit etmektedir. Model tahmin sonuçlarına göre alacak devir hızının kârlıı̆ı̆ pozitif olarak etkilemesi de Deloof'un (2003) alacak devir hızının artırılıp alacak tahsil süresinin azaltılmasıyla kârlıı̆ıı da artacağını savunan görüşleri ile aynı yöndedir. Alacakların etkin yönetimi ve hızlı bir şekilde tahsili yüksek kârlıı̆ı̆ da

${ }^{3} \mathrm{AKO}, \mathrm{CO}, \mathrm{KO}$ ve MDV/A değişkenleri \% olarak analize dahil edilmiştir.

${ }^{4}$ Birimlere ve zamanlara göre değiştiğinden, sabitlere (ai ve $\lambda \mathrm{t}$ ) tahmin sonuçlarında yer verilmemiştir. 
beraberinde getirmektedir. Diğer taraftan reel aktif büyüklüğü arttıkça aktif kârlıı̆ı̆ın da artması; büyük işletmelerin faaliyetlerini ve ürünlerini çeşitlendirebilmek için daha yüksek kapasiteye ve piyasadaki potansiyel rakiplerle rekabet edebilmek adına daha fazla güce sahip olduğunu ve işletmelerin büyüdükçe ölçek ekonomisinin avantajlarından daha kolay yararlandıklarını öne süren Gschwandtner'in (2005) görüşleriyle uyum göstermektedir.

\section{SONUÇ}

Türkiye imalat sanayi sektöründe kârlıığın belirleyicilerinin araştırılması amacıyla seçilen bağımsız değişkenlerin daha önceki benzer çalışmalardan yararlanılarak belirlendiği çalışmada; en geniş reel sektör veri setini sunan TCMB sektör bilançoları verileri kullanılarak panel veri analizi yardımıla bağımlı değişken konumundaki aktif kârlılık oranının hangi bağımsız değişkenler tarafından anlamlı olarak açıklandığının tespit edilmesi amaçlanmıştır. Çalışmada kullanılan ve durağan olmayan seriler, 1.farkları alınarak durağanlaştırılmış ve birim kök sorunu ortadan kaldırılmıştır. Kurulan panel veri regresyon modelleri otokorelasyon ve değişen varyans sorunlarından arındırılarak tahmin edilmiştir.

Model tahminlerinden elde edilen sonuçlar; imalat sanayi sektöründe aktif kârlılık oranlarının kaldıraç oranından ve maddi duran varlıkların toplam varlıklara oranından negatif; alacak devir hızı ve aktif büyüklüğünden pozitif olarak etkilendiğini ve cari orandan anlamlı olarak etkilenmediğini ortaya koymaktadır. Analiz sonuçlara göre imalat sanayi sektöründe aktif kârlılık oranlarının artırılması için varlıkların finansmanında daha fazla özkaynak kullanılmalı, maddi duran varlıklar daha verimli kullanılacak şekilde azaltılmalı ve alacaklar daha hızlı tahsil etmelidir. Analiz sonuçları, imalat sanayi sektöründe işletme düzeyindeki faktörlerin kârlılık oranları üzerinde anlamlı etkilere sahip olduğunu ve bu değişkenlerin kârlılıktaki değişimleri yüksek oranda açıkladığını göstermektedir.
Ülkemizdeki işletmeler, iç kaynakların yeterli düzeyde olmamasına bağlı olarak otofinansman imkânlarının dar olmasından ve dış kaynaklardan sağlanan özkaynak finansmanının yaygın olmamasından dolayı yabancı kaynak kullanmak zorunda kalmaktadır. Halka açılma maliyetlerinin düşürülmesi, ilgili bürokratik işlemlerin azaltılması ve hisse senedi ihracı yapacak işletmelere muafiyet ve istisna şeklinde daha cazip vergi teşvikleri sunulmasıyla gelişecek hisse senedi piyasaları ve melek finansman ve risk sermayesi gibi özkaynak finansman kaynaklarının yaygınlaşmasıyla artacak özkaynak finansman olanakları; imalat sanayi sektöründe yabancı kaynakların daha az oranda yer aldığı daha dengeli sermaye yapılarının kurulmasını sağlayabilecek ve kârlııı oranlarını düşüren borç kullanımıyla ilişkili finansal riskleri de azaltabilecektir. Ülkemizde büyüklük ve işlem hacmi olarak gelişmişülkelerin oldukça gerisinde kalan hisse senedi piyasasının gelişmesi ve alternatif özkaynak finansman araçlarının kullanımının artması, tasarrufları yatırımlara yönlendirerek sermaye birikimini hızlandıracak ve daha geniş fonlara ulaşım sağlayacak işletmelerin bir süre sonra ucuz maliyetli otofinansman imkânlarını da artırabilecektir. Diğer taraftan atıl haldeki maddi duran varlıkların aktif kârlılığını azaltıcı etkisi dikkate alındığında, imalat sanayi sektöründeki işletmelerin gerçekçi analizlerle tahmin edilen satış miktarlarını dikkate alarak kapasite planlamaları yapmaları verimlilik düzeylerini ve buna bağlı olarak kârlılık oranlarını da yükseltebilecektir. Alacak devir hızı ve kârlılık arasındaki pozitif ilişki çerçevesinde de alacak devir hızı düşük olan işletmelerin ekonominin genel şartlarını da dikkate alarak toplam satışların büyüme oranını düşürmeyecek şekilde kısa vadelerle çalışmaları ve müşterilerin risklerini iyi analiz edip etkin bir alacak yönetimi sağlamaları kârlılıklarını artırabilecektir. Sonuçta imalat sanayi sektöründeki işletmelerin daha kârlı faaliyet göstermeleriyle birlikte inovasyonlara, ihracata ve istihdama önemli katkılar sağlayan sektörün ekonomi içindeki payının artması, ülkemizde ekonomik büyümeyi ve kalkınmayı hızlandıracaktır.

\section{KAYNAKÇA}

Akdoğan, N. ve Tenker, N. (2007) Finansal Tablolar ve Mali Analiz Teknikleri, Ankara, Gazi Kitabevi.

Akgüç, Ö. (1998) Finansal Yönetim, İstanbul, Avcıol Basım Yayın.

Asteriou, D. ve Hall, S.G. (2007) Applied Econometrics, New York, Palgrave Macmillan.
Aydeniz, Ş. (2009) "Makroekonomik Göstergelerin Firmaların Finansal Performans Ölçütleri Üzerindeki Etkisinin Ölçülmesine Yönelik Bir Araştırma: IMKB'ye Kote Gıda ve İçecek İşletmeleri Üzerine Bir Uygulama" Marmara Üniversitesi I.I.B.F. Dergisi, XXVII( II): 263-277. 
Aygün, M. (2012)“Firma Performansı Üzerinde Çalışma Sermayesinin Etkisi: Türk İmalat Sektörü Üzerine Bir Uygulama" Ege Akademik Bakış, 12(2): 215-223.

Baker, M. ve Wurgler, J. (2002) "Market Timing and Capital Structure" The Journal of Finance, LVII(1): 1-32.

Baltagi B.H. (2005) Econometric Analysis of Panel Data, Wiltshire, John Wiley\&Sons.

Breitung, J. (2000) “The Local Power of Some Unit Root Tests for Panel Data" Baltagi B.H. (ed.) Nonstationary Panels, Panel Cointegration, and Dynamic Panels, Amsterdam, Elsevier, 161-177.

Breusch, T.S. ve Pagan, A.R. (1980) "The Lagrange Multiplier Test and its Applications to Model Specification in Econometrics, The Review of Economic Studies, 47(1), 239-253

Brooks, C. (2008) Introductory Econometrics for Finance, New York, Cambridge University Press.

Choi, I. (2001) "Unit Root Tests for Panel Data” Journal of International Money and Finance, 20(2), 249-272.

Deloof, M. (2003) “Does Working Capital Management Affect Profitability of Belgian Firms?" Journal of Business Finance\&Accounting, 30(3): 573-587.

Doğan, M. ve Topal, Y. (2016) "Kârlılığı Belirleyen Faktörler: BiST'te İşlem Gören İmalat Sanayi Firmaları Üzerine Bir Araştırma" Optimum Ekonomi ve Yönetim Bilimleri Dergisi, 3(1): 53-64.

Donaldson, G. (1961) Corporate Debt Capacity; A Study of Corporate Debt Policy and the Determination of Corporate Debt Capacity, Boston, Harvard University.

Eljelly, A.M.A. (2004) "Liquidity-Profitability Tradeoff: An Empirical Investigation in an Emerging Market" International Journal of Commerce and Management, 14(2): $48-61$.

Goddard, J., Tavakoli, M. ve Wilson J. (2005) "Determinants of Profitability in European Manufacturing and Services: Evidence from a Dynamic Panel Model" Applied Financial Economics, 15(18), 1269-1282.

Gönenç, R. ve Yılmaz, G. (2007), The Evolution and Determinants of Profitability in Turkish Manufacturing Industry, 1997-2006 (CBRT Research and Monetary Policy Department Working Paper No: 07/01), https://ideas.repec.org/p/tcb/wpaper/0701. html, (10.3.2017).

Granger, C.W.J. ve Newbold, P. (1974) "Spurious Regression in Econometrics" Journal of Econometrics, 2(1974): 111-120.

Grant, R.M. (1991) "The Resource-Based Theory of Competitive Advantage" Harvard Business Review, Spring 1991: 114-135.
Greene, W.H. (2003) Econometric Analysis, New Jersey, Pearson Education.

Gschwandtner, A. (2005) "Profit Persistance in the Very Long Run: Evidence from Survivors and Exiters" Applied Economics, 37(7): 793-806.

Gujarati, D.N. (2003) Basic Econometrics, New York, McGraw-Hill.

Hausman A.J. (1978) "Specification Tests in Econometrics" Econometrica, 46(6): 1251-1271.

Honda, Y. (1985) "Testing the Error Components Model with Non-normal Distribution" Review of Economic Studies, 52(4), 681-690.

Hsiao, C. (2007) “Panel Data Analysis-Advantages and Challenges" TEST, 16(1): 1-22.

Im, K.S., Pesaran, M.H. ve Shin, Y. (2003) "Testing for Unit Roots in Heterogeneous Panels" Journal of Econometrics, 115(1), 53-74.

Jensen, M.C. ve Meckling, W.H. (1976) "Theory of the Firm: Managerial Behavior, Agency Costs and Ownership Structure" Journal of Financial Economics, 3(4): 305-360.

Keskin, R. ve Gökalp, F. (2016) "Çalışma Sermayesi Yönetiminin Firma Kârlılığı Üzerine Etkisi: Panel Veri Analizi" Doğuş Üniversitesi Dergisi, 17(1): 15-25.

Kocaman, M., Altemur, N., Aldemir, S. ve Karaca, S.S. (2016) "Ekonomik Kârlılığı Etkileyen Faktörler: ISO 500 Sanayi İşletmeleri Uygulaması" Mustafa Kemal Üniversitesi S.B.E. Dergisi, 13(35): 320-332.

Korkmaz, Ö. ve Karaca, S.S. (2014) “Üretim İşletmelerinde Firma Kârlılığının Finansal Belirleyicileri ve BIST İmalat Sanayi Uygulaması" Ege Akademik Bakış, 14(1): 21-29.

Kraus, A. ve Litzenberger, R.H. (1973) "A StatePreference Model of Optimal Financial Leverage" Journal of Finance, 28(4): 911-922.

Leiponen, A. (2000) "Competencies, Innovation and Profitability of Firms" Economics of Innovation and New Technology, 9(1), 1-24.

Levin, A., Lin, C.F. ve Chu, C. J. (2002) "Unit Root Tests in Panel Data: Asymptotic and Finite-Sample Properties" Journal of Econometrics, 108(1): 1-24.

Maddala, G.S. ve Wu, S. (1999) "A Comparative Study of Unit Root Tests with Panel Data and a New Simple Test" Oxford Bulletin of Economics and Statistics, 61(S1), 631-652.

McKinsey (2012), Manufacturing the Future: The Next Era of Global Growth and Innovation, http://www. mckinsey.com/business-functions/operations/ourinsights/the-future-of-manufacturing, (12.11.2016). 
Meder Çakır, H. ve Küçükkaplan, İ. (2012) "Işsletme Sermayesi Unsurlarının Firma Değeri ve Kârlılık Üzerindeki Etkisinin IMKB'de İşlem Gören Üretim Firmalarında 2000-2009 Dönemi İçin Analizi" Muhasebe ve Finansman Dergisi, Ocak 2012: 69-86.

Modigliani, F. ve Miller, M.H. (1958) "The Cost of Capital, Corporation Finance and the Theory of Investment" The American Economic Review, XLVIII(3): 261-297.

Modigliani, F. ve Miller, M.H. (1963) "Corporate Income Taxes and the Cost of Capital: A Correction" The American Economic Review, 53(3): 433-443.

Myers, S.C. (1984) "The Capital Structure Puzzle" The Journal of Finance, 39(3): 574-592.

Myers, S.C. ve Majluf, N.S. (1984) “Corporate Financing and Investment Decisions When Firms Have Information That Investors Do Not Have" Journal of Financial Economics, 13(1984): 187-221.

Nazir, M.S. ve Afza, T. (2009). "Working Capital Requirements and the Determining Factors in Pakistan" The Icfai Journal of Applied Finance, 15(4): 28-38.

Otley, D. (2002) "Measuring Performance: The Accounting Perspective" Neely, A (ed.) Business Performance Measurement: Theory and Practice, Cambridge, Cambridge University Press, 3-21.

Özmen, E., Şahinöz, S. ve Yalçın, C. (2012) “Profitability, Saving and Investment of Non-Financial Firms in Turkey" (Working Paper No: 12/14), Central Bank of the Republic of Turkey.

Ratnayake, R. (2000) "Manufacturing Profitability, Monopoly Power and Efficiency in a Small Economy: Implications on Competition Policies" The Korean Economic Review, 16(1), 149-163.

Reed, R.W. ve Ye, H. (2011)“Which Panel Data Estimator Should I Use?" Applied Economics, (45): 985-1000.

Ritchie, F., Thomas, A.D. ve Welpton, R. (2012), What's a Manufacturing Job? (Working Paper. University of the West of England), http://eprints.uwe.ac.uk/22517, (9.11.2016)

Saldanlı, A. (2012) "Likidite ve Kârlılık Arasındaki Ilişki: IMKB 100 Imalat Sektörü Üzerine Ampirik Bir Çalışma" Süleyman Demirel Üniversitesi S.B.E. Dergisi, 2(16): 167176.

Shin, H. ve Soenen, L. (1998) "Efficiency of Working Capital Management and Corporate Profitability" Financial Practice \& Education, 8(2): 37-45.

Slade, M.E. (2004) "Competing Models of Firm Profitability" International Journal of Industrial Organization, 22(3): 289-308.

Smith, K. (1980) "Profitability versus Liquidity Tradeoffs in Working Capital Management" Smith, $\mathrm{K}$. et al (eds.) Reading on the Management of Working Capital, USA, West Publishing Firm, 549-562.

Stierwald, A. (2009), Determinants of Firm Profitability: The Effect of Productivity and Its Persistence, https:// editorialexpress.com/cgi-bin/conference/download. cgi?db_name=ESAM09\&paper_id=152, (22.11.2016)

Torres-Reyna, O. (2007), Panel Data Analysis: Fixed and Random Effects Using Stata, https://www.princeton. edu/ otorres/Panel101.pdf, (10.11.2016).

Uluyol, O., Lebe, F. ve Akbaş, Y.E. (2014) "Firmaların Finansal Kaldıraç Oranları ile Özsermaye Kârlılı̆ı Arasındaki Iliş̧ki: Hisseleri BiST'te İşlem Gören Şirketler Üzerinde Sektörler Bazında Bir Araştırma" İşletme Araştırmaları Dergisi, 6(1): 70-89.

Van Horne, J.C. ve Wachowicz, J.M. (2008) Fundamentals of Financial Management, London, Pearson Education.

Wooldridge, J.M. (2012) Introductory Econometrics: A Modern Approach, Ohio, Cengage Learning.

WTO (World Trade Organization) (2015) International Trade Statistics 2015, Geneva.

tcmb.gov.tr (Türkiye Cumhuriyet Merkez Bankası)

tuik.gov.tr (Türkiye İstatistik Kurumu) 
